\title{
Duodenal bile acids in infants with protracted diarrhoea
}

\author{
D. N. CHALlACOMBE, G. A. BROWN, AND SUSAN EDKINS \\ Institute of Child Health, University of Birmingham
}

SUMMARY Bile acids were estimated in the duodenum of infants with protracted diarrhoea and compared with those in a control group. Significantly lower levels of total bile acids were found in infants with protracted diarrhoea, a finding which may be due to ileal dysfunction. Low concentrations of total bile acids may contribute to the poor nutritional state of these patients by impairing the normal digestion and absorption of dietary fat and fat-soluble vitamins. The absence of deconjugated bile acids in the duodenal juice of most infants with protracted diarrhoea suggests that they do not contribute significantly to the pathophysiology of this disorder.

Protracted diarrhoea of infancy is a severe and debilitating disorder, characterised by the passage of at least 4 loose stools a day for more than 2 weeks. In some infants protracted diarrhoea is secondary to recognised gastrointestinal diseases (Larcher et al., 1977), while in others the pathogenesis remains unknown. The patients become dehydrated and malnourished due to persistent fluid loss and to difficulty in maintaining an adequate oral intake of food. Impaired digestion and absorption, resulting from a damaged small intestinal mucosa, also contribute to the poor nutritional state. As recovery of small intestinal mucosal function may be delayed by malnutrition, a vicious cycle of events occurs which perpetuates the clinical problem, and intravenous nutrition may be needed to sustain life.

Bile acid studies on infants with protracted diarrhoea have shown two principal abnormalities, either of which could contribute to the pathophysiology of this disorder. Deconjugated bile acids were detected in the duodenal juice of some infants (Gracey et al., 1969), while in experimental animals the same bile acids had cytopathic effects on the small intestinal mucosa (Dawson and Isselbacher, 1960), and inhibited the absorption of water, electrolytes, and monosaccharides from the lumen of the small intestine (Gracey et al., 1971; Harries and Sladen, 1972). Increased faecal excretion of bile acids has also been shown in infants with protracted

Institute of Child Health, University of Birmingham

D. N. CHALLACOMBE, lecturer

G. A. BROWN, research fellow

SUSAN EDKINS, senior technician diarrhoea (Balistreri et al., 1977). If the loss is prolonged, it may reduce the size of the bile acid pool and lower the concentration of bile acids in the small intestine. As bile acids are essential for the optimal absorption of dietary fat and fat-soluble vitamins, a fall in concentrations below the level at which micelle formation occurs in the small intestine might further compromise the poor nutritional state of the patient. Bile acids in the duodenum of a control group of infants (group A) were therefore compared with those in a group of infants with protracted diarrhoea (group B).

\section{Materials and methods}

Patients. The infants were divided into two groups (Table 1). Infants with protracted diarrhoea (group

Table 1 Clinical details of infants studied

\begin{tabular}{|c|c|c|c|}
\hline Cases & $\begin{array}{l}\text { Age } \\
\text { (weeks) }\end{array}$ & Sex & Diagnosis \\
\hline \multicolumn{4}{|c|}{ Group A (controls) } \\
\hline 1 & 2 & $\mathbf{M}$ & Inguinal hernia \\
\hline 2 & 5 & $\mathbf{F}$ & Feeding problem \\
\hline 3 & 8 & $\mathbf{M}$ & Congenital heart disease \\
\hline 4 & 8 & $\mathbf{M}$ & Congenital heart disease \\
\hline 5 & 12 & $\mathbf{F}$ & Feeding problem \\
\hline \multicolumn{4}{|c|}{ Group $B$ (patients) } \\
\hline 6 & 6 & $\mathbf{M}$ & Protracted diarrhoea \\
\hline 7 & 6 & $\mathbf{M}$ & $\begin{array}{l}\text { Protracted diarrhoea }+ \text { secondary glucose } \\
\text { intolerance }\end{array}$ \\
\hline 8 & 8 & $\mathbf{M}$ & $\begin{array}{l}\text { Protracted diarrhoea }+ \text { secondary lactose } \\
\text { intolerance }\end{array}$ \\
\hline 9 & 8 & $\mathbf{F}$ & Protracted diarrhoea \\
\hline 10 & 12 & $\mathbf{F}$ & $\begin{array}{l}\text { Protracted diarrhoea }+ \text { secondary glucose } \\
\text { intolerance }\end{array}$ \\
\hline
\end{tabular}


B) had been passing at least 4 loose stools daily for more than 2 weeks, without the isolation of known enteropathogenic bacteria. Stools were tested for the presence of reducing substances using Clinitest tablets (Kerry and Anderson, 1964), and significant amounts $(>0.5 \%)$ were detected in 3 of them. The presence of glucose was confirmed by paper chromatography in 2 patients and lactose in one. All the infants in the control group (group A) needed tube feeding as a normal part of their medical care, and none had diarrhoea. As concentrations of duodenal bile acids have been shown to increase with age in early infancy (Challacombe et al., 1975), these infants were of approximately similar ages as those in group $\mathbf{B}$.

Sampling regimen. Duodenal juice was obtained by the use of a long polyethylene feeding catheter (Argyl, 5 FG, $91 \mathrm{~cm}$ ), weighted with a gold bead (Rhea and Kilby, 1970). The distal end of the tube was allowed to pass into the duodenum by normal peristalsis and its position in the 2nd to 4th part of the duodenum was confirmed by screening. The first sample of duodenal juice aspirated was discarded to exclude contamination by gastric juice and the 2 nd sample was placed in a sterile container and stored at $-20^{\circ} \mathrm{C}$ until analysed. Samples were taken 2 hours after a full cream cows' milk formula feed in group A and 2 hours after a $5 \%$ glucose feed in group $\mathrm{B}$. The absence of significant differences in duodenal bile acid concentrations in infants 2 hours after either type of feed has been previously demonstrated (Challacombe et al., 1975).

Bile acid analysis. Bile acids were estimated using sulphuric acid fluorescence after separation by thin layer chromatography (Panveliwalla et al., 1970). Total and individual bile acids were measured in samples of duodenal bile from both groups of infants. Separate estimates of the individual taurine and glycine conjugated dihydroxy bile acids were not made because it was not possible to separate them by the chromatographic method.

\section{Results}

The results of bile acid analyses are shown in Table 2 . The difference between mean values of total bile acids, taurine, and glycine conjugates, and individual bile acids in group A and group B were examined for statistical significance using Student's $t$ test. Differences were regarded as significant when $P$ values were $<0.05$.

Concentrations of total bile acids were significantly lower in infants in group $B(P<0 \cdot 01)$. This finding was mainly due to lower mean concentrations of taurocholic $(\mathrm{P}<0.01)$ and glycocholic acids $(\mathrm{P}<0.05)$. Ratios of total glycine conjugates to total

Table 2 Duodenal bile acids (mmol/l)

\begin{tabular}{|c|c|c|c|c|c|c|c|c|c|c|}
\hline \multirow[t]{3}{*}{ Cases } & \multirow{3}{*}{$\begin{array}{l}\text { Total } \\
\text { bile acids }\end{array}$} & \multicolumn{3}{|c|}{ Conjugates } & \multirow{3}{*}{$\begin{array}{l}\text { Deconju- } \\
\text { gated bile } \\
\text { acids }\end{array}$} & \multirow{3}{*}{$\begin{array}{l}\text { Tauro- } \\
\text { cholic } \\
\text { acid }\end{array}$} & \multirow{3}{*}{$\begin{array}{l}\text { Taurine } \\
\text { conjugated } \\
\text { dihydroxy } \\
\text { bile acids }\end{array}$} & \multirow{3}{*}{$\begin{array}{l}\text { Tauro- } \\
\text { lithocholic } \\
\text { acid }\end{array}$} & \multirow{3}{*}{$\begin{array}{l}\text { Glycocholic } \\
\text { acid }\end{array}$} & \multirow{3}{*}{$\begin{array}{l}\text { Glycine } \\
\text { conjugated } \\
\text { dihydroxy } \\
\text { bile acids }\end{array}$} \\
\hline & & \multirow[t]{2}{*}{ Glycine } & \multirow[t]{2}{*}{ Taurine } & Glycine & & & & & & \\
\hline & & & & Taurine & & & & & & \\
\hline $\begin{array}{l}\text { Group } A \text { (cont } \\
1 \\
2 \\
3 \\
4 \\
5\end{array}$ & $\begin{array}{l}\text { trols) } \\
5 \cdot 4 \\
7 \cdot 1 \\
9 \cdot 1 \\
6 \cdot 1 \\
9 \cdot 8\end{array}$ & $\begin{array}{l}1 \cdot 4 \\
4 \cdot 0 \\
6 \cdot 3 \\
5 \cdot 0 \\
6 \cdot 4\end{array}$ & $\begin{array}{l}3 \cdot 9 \\
3 \cdot 0 \\
2 \cdot 8 \\
1 \cdot 0 \\
3 \cdot 3\end{array}$ & $\begin{array}{l}0 \cdot 3 \\
1 \cdot 3 \\
2 \cdot 2 \\
5 \cdot 0 \\
1 \cdot 9\end{array}$ & $\begin{array}{l}- \\
- \\
-\end{array}$ & $\begin{array}{l}1 \cdot 6 \\
1 \cdot 4 \\
1 \cdot 4 \\
0 \cdot 4 \\
1 \cdot 3\end{array}$ & $\begin{array}{l}2 \cdot 3 \\
1 \cdot 1 \\
1 \cdot 1 \\
0 \cdot 3 \\
1 \cdot 3\end{array}$ & $\begin{array}{l}\text { ND } \\
0.5 \\
0.3 \\
0.4 \\
0.7\end{array}$ & $\begin{array}{l}1 \cdot 0 \\
3 \cdot 1 \\
3 \cdot 1 \\
3 \cdot 6 \\
3 \cdot 9\end{array}$ & $\begin{array}{l}0.5 \\
1 \cdot 0 \\
3 \cdot 2 \\
1 \cdot 4 \\
2 \cdot 5\end{array}$ \\
\hline \multicolumn{11}{|c|}{$\begin{array}{l}\text { Coefficient of } \\
\text { variation }(\%) 25 \\
\text { Group B patients }\end{array}$} \\
\hline $\begin{array}{r}6 \\
7 \\
8 \\
9 \\
10\end{array}$ & $\begin{array}{l}2 \cdot 1 \\
7 \cdot 1 \\
2 \cdot 8 \\
1 \cdot 4 \\
2 \cdot 1\end{array}$ & $\begin{array}{l}1 \cdot 6 \\
4.9 \\
1 \cdot 6 \\
0 \cdot 6 \\
1 \cdot 0\end{array}$ & $\begin{array}{l}0 \cdot 6 \\
2 \cdot 2 \\
0 \cdot 2 \\
0 \cdot 8 \\
1 \cdot 1\end{array}$ & $\begin{array}{l}2 \cdot 6 \\
2 \cdot 2 \\
8 \cdot 0 \\
0 \cdot 7 \\
0.9\end{array}$ & $\begin{array}{l}- \\
\overline{0.9} \\
-\end{array}$ & $\begin{array}{l}0.5 \\
0.5 \\
\text { ND } \\
0.2 \\
0.4\end{array}$ & $\begin{array}{l}0 \cdot 1 \\
1 \cdot 3 \\
0 \cdot 2 \\
0 \cdot 3 \\
0 \cdot 5\end{array}$ & $\begin{array}{l}\text { ND } \\
0.4 \\
\text { ND } \\
0 \cdot 2 \\
0.2\end{array}$ & $\begin{array}{l}1 \cdot 6 \\
2 \cdot 4 \\
1 \cdot 3 \\
0 \cdot 7 \\
0 \cdot 6\end{array}$ & $\begin{array}{l}\text { ND } \\
2 \cdot 5 \\
0.4 \\
\text { ND } \\
0.4\end{array}$ \\
\hline $\begin{array}{l}\text { Mean } \\
\text { SD } \\
\text { Coefficient of }\end{array}$ & $\begin{array}{l}3 \cdot 1 \\
2 \cdot 3\end{array}$ & $1 \cdot 9$ & $\begin{array}{l}1 \cdot 0 \\
0 \cdot 7\end{array}$ & $\begin{array}{l}2 \cdot 9 \\
2 \cdot 9\end{array}$ & - & $\begin{array}{l}0 \cdot 3 \\
0 \cdot 2\end{array}$ & $\begin{array}{l}0 \cdot 5 \\
0 \cdot 5\end{array}$ & $\begin{array}{l}0 \cdot 2 \\
0 \cdot 2\end{array}$ & $\begin{array}{l}1 \cdot 3 \\
0 \cdot 7\end{array}$ & $\begin{array}{l}0.6 \\
1 \cdot 0\end{array}$ \\
\hline variation (\%) & 74 & 89 & 75 & 103 & & 62 & 100 & 100 & 53 & 173 \\
\hline $\begin{array}{l}t \\
\mathrm{P}\end{array}$ & $\begin{array}{r}3 \cdot 3 \\
<0.01 \\
\end{array}$ & $\begin{aligned} & 2.3 \\
< & 0.05\end{aligned}$ & $\begin{aligned} & 3.2 \\
< & 0.01\end{aligned}$ & $\begin{aligned} & 0.46 \\
> & 0.3\end{aligned}$ & & $\begin{aligned} & 3.8 \\
< & 0.01\end{aligned}$ & $\begin{array}{c}1.9 \\
>0.05\end{array}$ & $\begin{array}{r}1.6 \\
>0.1\end{array}$ & $\begin{array}{l}2.7 \\
<0.05\end{array}$ & $\begin{array}{r}1 \cdot 6 \\
>0 \cdot 1\end{array}$ \\
\hline
\end{tabular}

ND $=$ not detected.

Conversion: SI to traditional units-Taurocholic acid: $1 \mathrm{mmol} / 1 \approx 51.5 \mathrm{mg} / 100 \mathrm{ml}$. Taurine conjugated dihydroxy bile acids: $1 \mathrm{mmol} / 1 \approx 49 \cdot 9$ $\mathrm{mg} / 100 \mathrm{ml}$. Taurolithocholic acid: $1 \mathrm{mmol} / 1 \approx 43.8 \mathrm{mg} / 100 \mathrm{ml}$. Glycocholic acid: $1 \mathrm{mmol} / 1 \approx 46.5 \mathrm{mg} / 100 \mathrm{ml}$. Glycine conjugated dihydroxy bile acids: $1 \mathrm{mmol} / 1 \approx 44.9 \mathrm{mg} / 100 \mathrm{ml}$. 
taurine conjugates $(\mathrm{G} / \mathrm{T})$ were not significantly different in the two groups. Mean concentrations of taurine conjugated dihydroxy bile acids, glycine conjugated dihydroxy bile acids, and taurolithocholic acid were also not significantly different. In group B taurocholic acid was present in 4 out of 5 , taurolithocholic acid in 3 out of 5 , and glycine conjugated dihydroxy bile acids in 3 out of 5 infants. In group $A$ all bile acids were present with the exception of taurolithocholic acid which was not detected in one patient. Deconjugated bile acids were not detected in infants in group A, but cholic acid $(0 \cdot 13 \mathrm{mmol} / 1 ; 5 \cdot 3 \mathrm{mg} / 100 \mathrm{ml})$, chenodeoxycholic acid $(0.57 \mathrm{mmol} / 1 ; 22.3 \mathrm{mg} / 100 \mathrm{ml})$, and lithocholic acid $(0.25 \mathrm{mmol} / \mathrm{l} ; 9.4 \mathrm{mg} / 100 \mathrm{ml})$ were found in the duodenal juice of one infant in group $B$ who had secondary lactose intolerance. In this infant, who has been previously reported (Challacombe et al., 1974a), Bacteroides sp. (obligate anaerobes with known bile acid deconjugating properties in vitro) were isolated from the duodenal juice.

\section{Discussion}

Concentrations of total bile acids were significantly lower in the duodenum of infants in group B compared with group A. Morphological and functional changes in the bowel may interrupt the enterohepatic circulation of bile acids leading to increased bile acid excretion in the faeces. The liver initially compensates for the increased faecal loss by increased synthesis, but eventually synthesis is inadequate, leading to a depleted bile acid pool and to low levels of bile acids in the duodenum. There is some experimental evidence in favour of this proposed mechanism. The oral or intravenous administration of radioactively-labelled bile acids to adults with diffuse ileal disease leads to rapid excretion of the radioactive label in the faeces (Meihoff and Kern, 1968). Oral administration of $\mathrm{C}^{\mathbf{1 4}}$-cholic acid to infants with ileal resections and to infants with protracted diarrhoea also results in increased faecal excretion of this label (Balistreri et al., 1977). The presence of ileal dysfunction in protracted diarrhoea is further suggested by abnormal Schilling tests for vitamin B12 absorption (Balistreri et al., 1977). Impaired ileal function may be the result of associated mucosal damage. Severe mucosal changes have been reported in the upper small intestine (Greene et al., 1975) and these may be sufficiently extensive to involve the terminal ileum where most bile acid reabsorption should occur. Ileal dysfunction may also contribute to the protracted diarrhoea in these patients, as excessive amounts of dihydroxy bile acids reaching the colon have been shown to provoke excessive water secretion by the colonic mucosa (Mekhjian et al., 1971).

A higher ratio of glycine to taurine conjugates in duodenal bile is usually present in adults with terminal ileal disorders (Heaton et al., 1968), a finding which may be due to the relative scarcity of taurine or of its precursor cysteine, in the face of an increased demand for bile acid conjugation. Mean values of the glycine/taurine ratio were not significantly raised in patients with protracted diarrhoea compared with the controls. As bile acids are mainly conjugated with taurine in early infancy, failure to demonstrate consistently raised glycine/taurine ratios in patients with protracted diarrhoea may be due to an increased availability of taurine for conjugation.

Trihydroxy bile acid concentrations were significantly lower in infants in group B compared with group A, and mean concentrations of dihydroxy bile acids were also low, but the values did not reach statistical significance. In adults with ileal resections the absorption of both dihydroxy and trihydroxy bile acids has been shown to be equally impaired (Low-Beer et al., 1974). Although ileal dysfunction may be one explanation for the bile acid findings reported in protracted diarrhoea, further study of the enterohepatic circulation and faecal excretion of bile acids in this disorder will be necessary. Bacterial overgrowth in the upper small intestine (Gracey and Stone, 1972; Challacombe et al., 1974b), a rapid small intestinal transit time, or impaired synthesis of bile acids by the liver due to malnutrition, could each influence bile acid metabolism in infants with protracted diarrhoea.

The deconjugated bile acids, deoxycholic and chenodeoxycholic acids, have been shown to have cytopathic and metabolic-inhibitory effects on the small intestine of experimental animals (Dawson and Isselbacher, 1960; Low-Beer et al., 1970; Gracey et al., 1971; Harries and Sladen, 1972), and these bile acids could have similar effects in patients with protracted diarrhoea and monosaccharide malabsorption (Gracey et al., 1969). Cholic, chenodeoxycholic, and lithocholic acids were detected in small quantities in only one infant with protracted diarrhoea, an infant who was also intolerant of oral lactose. These findings suggest that deconjugated bile acids were not important in the pathophysiology of protracted diarrhoea in our patients, but samples were taken from a single site only in the duodenum, and sampling from other sites will be necessary before the contribution of deconjugated bile acids can be fully evaluated. Concentrations of total bile acids in the duodenum of 4 of the 5 infants in group B were below a level of $4 \mathrm{mmol} / 1$. Badley $e t$ al. (1969) have shown that total bile acid concentrations in the upper small intestine should exceed this value 
for optimal fat absorption to occur. The digestion and absorption of dietary fat and fat-soluble vitamins may therefore be impaired in patients with protracted diarrhoea, and absorption and nutrition may be improved by the use of medium chain triglycerides, which are well absorbed in the absence of bile acids.

We are grateful for the advice and assistance given to us by Professor Charlotte M. Anderson. D.N.C. was supported by a grant from the Endowment Fund of the United Birmingham Hospitals and S.E. from the Medical Research Council.

\section{References}

Badley, B. W. D., Murphy, G. M., and Bouchier, I. A. D. (1969). Intraluminal bile salt deficiency in the pathogenesis of steatorrhoea. Lancet, 2, 400-402.

Balistreri, W. F., Partin, J. C., and Schubert, W. K. (1977). Bile acid malabsorption-a consequence of terminal ileal dysfunction in protracted diarrhoea of infancy. Journal of Pediatrics, 90, 21-28.

Challacombe, D. N., Richardson, J. M., and Edkins, S. (1974a). Anaerobic bacteria and deconjugated bile salts in the upper small intestine of infants with gastrointestinal disorders. Acta paediatrica Scandinavica, 63, 581-587.

Challacombe, D. N., Richardson, J. M., Rowe, B., and Anderson, C. M. (1974b). Bacterial microflora of the upper gastrointestinal tract in infants with protracted diarrhoea. Archives of Disease in Childhood, 49, 270-277.

Challacombe, D. N., Edkins, S., and Brown, G. A. (1975). Duodenal bile acids in infancy. Archives of Disease in Childhood, 50, 837-843.

Dawson, A. M., and Isselbacher, K. J. (1960). Studies on lipid metabolism in the small intestine with observations on the role of bile salts. Journal of Clinical Investigation, 39, 730-740.

Gracey, M., Burke, V., and Anderson, C. M. (1969). Association of monosaccharide malabsorption with abnormal small intestinal flora. Lancet, 2, 384-385.

Gracey, M., Burke, V., Oshin, A., Barker, J., and Glasgow, E. F. (1971). Bacteria, bile salts, and intestinal monosaccharide malabsorption. Gut, 12, 683-692.

Gracey, M., and Stone, D. E. (1972). Small intestinal microflora in Australian aboriginal children with chronic diarrhoea. Australian and New Zealand Journal of Medicine, 2, 215-219.
Greene, H. L., McCabe, D. R., and Merenstein, G. B. (1975). Protracted diarrhoea and malnutrition in infancy: changes in intestinal morphology and disaccharidase activities during treatment with total intravenous nutrition or oral elemental diets. Journal of Pediatrics, 87, 695-704.

Harries, J. T., and Sladen, G. E. (1972). The effects of different bile salts on the absorption of fluid, electrolytes, and monosaccharides in the small intestine of the rat in vivo. Gut, 13, 596-603.

Heaton, K. W., Austad, W. I., Lack, L., and Tyor, M. P. (1968). Enterohepatic circulation of $C^{14}$-labelled bile salts in disorders of the distal small bowel. Gastroenterology, 55, 5-16.

Kerry, K. R., and Anderson, C. M. (1964). A ward test for sugar in faeces. Lancet, 2, 981-982.

Larcher, V. F., Shepherd, R., Francis, D. E. M., and Harries, J. T. (1977). Protracted diarrhoea in infancy: analysis of 82 cases with particular reference to diagnosis and management. Archives of Disease in Childhood, 52, 597-605.

Low-Beer, T. S., Schneider, R. E., and Dobbins, W. O. (1970). Morphological changes in the small intestinal mucosa of guinea pig and hamster, following incubation in vitro and perfusion in vivo with unconjugated bile salts. Gut, 11, 486-492.

Low-Beer, T. S., Wilkins, R. M., Lack, L., and Tyor, M. P. (1974). Effect of one meal on enterohepatic circulation of bile salts. Gastroenterology, 67, 490-497.

Meihoff, W. E., and Kern, F., Jr (1968). Bile salt mal-

absorption in regional ileitis, ileal resection, and mannitolinduced diarrhoea. Journal of Clinical Investigation, 47, 261-267.

Mekhjian, H. S., Phillips, S. F., and Hofmann, A. F. (1971). Colonic secretion of water and electrolytes induced by bile acids: perfusion studies in man. Journal of Clinical Investigation, 50, 1569-1577.

Panveliwalla, D., Lewis, B., Wootton, I. D. P., and Tabaqchali, S. (1970). Determination of individual bile acids in biological fluids by thin layer chromatography and fluorimetry. Journal of Clinical Pathology, 23, 309-314.

Rhea, J. W., and Kilby, J. O. (1970). A nasojejunal tube for infant feeding. Pediatrics, 46, 36-40.

Correspondence to Dr D. N. Challacombe, Consultant Paediatrician, The Children's Research Unit, Taunton and Somerset Hospital, Musgrove Park, Taunton, Somerset.

Received 22 May 1978 